\title{
Intermodális közlekedési központ Debrecenben
}

A publikáció szerencsésen ötvözi a megvalósított külföldi példák, valamint a város, mint település igényeit, és jól kapcsolja össze a település és közlekedéspolitika szét nem választható alapelvét. Értéket jelent a településszerkezet és a földrajz oldaláról való közelítés és az intermodális központ, mint optimális megoldás bemutatása, a helyi és helyközi közlekedés egységének biztosítása.

DOI 10.24228/KTSZ.2018.3.3

\section{Bodnár Balázs}

\author{
doktorandusz \\ Debreceni Egyetem Földtudományok Doktori Iskola \\ Társadalomföldrajzi és Területfejlesztési Tanszék \\ e-mail: bodnar.balazshome@gmail.com
}

\section{BEVEZETÉS}

Az elmúlt közel egy évszázad urbanizációja az olcsó szénhidrogén és a növekvő motorizáció logikájára épült [1.]. Az utakon megjelenő, drasztikus számú személygépjármü városaink kereteit egyre jobban szétfeszíti, kapacitási problémákat okozva ezzel a közlekedési ágazatban, jelentősen korlátozva a fenntartható településfejlesztési lehetőségeket. A problémát közösségi szinten is felismerték, és az beépült a mai kor közlekedésstratégiai gondolkozásába. Az Európai Unió az "EURÓPA $2020-$ Az intelligens, fenntartható és inkluzív növekedés stratégiájá"-nak három fő prioritásával kíván iránymutatást adni a nemzeti célkitűzések eléréséhez. A stratégiának a fenntartható növekedés prioritásán belüli, erőforrás-hatékony Európa nevü kiemelt kezdeményezésében láthatjuk, hogy a közlekedési ágazat modernizálása európai szinten előtérben lévő feladat, amelyhez kézenfekvő eszközként kerültek ajánlásra az intermodális közlekedési központok [2].
A fenntartható fejlődés mára már a tervezési-fejlesztési gyakorlat alapvető paradigmájává vált [3], ami igaz a közlekedési szektorra is. Megfigyelhető, hogy Európában az intermodális közösségi közlekedési központok meghatározó elemei a közlekedésben résztvevők mindennapi életének. Az európai városi társadalmak mindennapjait egyre több térszínen alakítják az újonnan létesült intermodális központok, nélkülözhetetlen részét képezve a fenntartható mobilitásnak [4]. Az elmúlt években megvalósított, példaértékűnek számító beruházások (pl. Rotterdam Centraal Station, 2014., Wien Hauptbahnhof, 2014., Reggio Emilia Railway Station, 2013.) rámutattak arra, hogy a megvalósított intermodális központok a város egyik legfontosabb tér- és városarculat-képző elemévé váltak, miközben egyszerre biztosították a közlekedési és a nem közlekedési funkciókat. Debrecen Megyei Jogú Város az európai példákhoz hasonló közlekedési központot kíván megvalósítani. Ennek a kialakítása egy olyan 
városépítészeti, építészeti és közlekedéstervezési eszközökkel történő városfejlesztési beavatkozás lesz, amivel egy modern, mindenki által használható, a különböző közlekedési módok közötti intermodalitást megteremtő központ jöhet létre, amely megváltoztatja a város regionális kapcsolatrendszerét, és a városi teret is [5]. Tanulmányomban e közlekedési központ részleteit, technikai megoldásait, innovációit mutatom be, és egyúttal részletezem a közlekedésfejlesztési projektet.

\section{INTERMODÁLIS KÖZPONTOK}

Fontos azt meghatározni, hogy mit is értünk az intermodális közlekedés és az intermodális közlekedési központok alatt.

$\mathrm{Az}$ intermodális közlekedés alapját képező intermodalitás a közlekedés feltételeinek kialakítása a közlekedési munkamegosztás optimalizálhatósága alapján. Egyértelmüen ez a leghatékonyabb közlekedési forma, ami csökkenti az utakon jelentkező torlódásokat [6], és kétség kívül a legtöbbet ígérő szemlélet arra, hogy elérjük napjaink egyik legfontosabb célját, az üvegházhatású gázok kibocsátásának csökkentését [7]. Az intermodális központ (csomópont) általánosságban egy-egy nagyobb városi, városkörnyéki térség forgalmát szabályozó, az adott intermodális közlekedési rendszer szempontjából meghatározó jelentőségű csomópontként definiálható [8]. Az intermodális központ a személyszállítás eszközváltó pontja [9], amely főként az autóbusz, a vonat és más közlekedési módok fizikai integrációjaként értelmezhető [10], és egyben interface a közlekedés és a városi élet egyéb funkciói között [11].

\section{DEBRECEN MEGYEI JOGÚ VÁROS RÖVID BEMUTATÁSA}

Debrecen Magyarország Észak-Alföldi Régiójának közepén, terület és népesség alapján az ország negyedik legnagyobb megyéjében, Hajdú-Bihar megyében található. A város egyben teljes értékű regionális központ és megyeszékhely is. Területe $462 \mathrm{~km}^{2}$, lakossága 204000 fö (2016). Debrecen központi szerepet tölt be abban a tizenhárom településböl álló településegyüttesben (területe: $1082 \mathrm{~km}^{2}$ [12]), amelynek tagja még Bocskaikert, Ebes, Hajdúbagos, Hajdúhadház, Hajdúsámson, Hosszúpályi, Mikepércs, Monostorpályi, Nyírmártonfalva, Sáránd, Téglás, Vámospércs is [13].

Debrecen történelmi városként oktatási, gazdasági, kereskedelemi, valamint kulturális, idegenforgalomi központja a tiszántúli régiónak [14].

\subsection{Oktatás}

A város napjainkban is a hazai oktatás egyik központjának számít. Az egyetemek müködése, vonzó hatása meghatározó a városfejlesztésben [15]. A felsőoktatás gyökere a 16. századig nyúlik vissza. A Debreceni Egyetem az ország legrégebbi, folyamatosan müködő felsőoktatási intézménye. Kiemelt kutatóegyetem, amely 14 karral, 23 doktori iskolával és 26994 fö (2016/2017) aktív hallgatóval büszkélkedhet. A külföldi hallgatók száma is egyre növekszik. Míg a külföldi hallgatói létszám 2015-ben 3968 fö [16] volt, addig 2016-ban már 4465 fő [17]. A külföldi diákok több mint a fele (54\%) [16] az orvosi kar hallgatója. Az egyetem nemcsak a hazai és a nemzetközi oktatás terén, hanem a kutatás, innováció és fejlesztés, valamint a vállalati szférával való kapcsolattartás terén is élen jár. A város tudományos életéből kiemelhető a Klinikai Központ, amely európai színvonalú betegellátó tevékenységet végez, teljes körű ellátást nyújtva a város, a megye, a régió és sok esetben országos betegellátási kötelezettsége révén.

\subsection{Gazdaság, kereskedelem}

Egy adott térség közlekedési infrastruktúra kiépítettsége és a kedvező közlekedésföldrajzi helyzete nagyban befolyásolja a gazdasági versenyképességet. Debrecen regionális központként Magyarország és az országrész fejlődését meghatározó pólus, amely regionális gazdasági, irányítási szerepet lát el [18]. Kiemelkedően magas (86) az ezer lakosra jutó vállalkozások száma [12]. Ha a vállalati méretet pénzügyi aspektusból vizsgáljuk, akkor is szembeötlik Debrecen súlyponti szerepe 
(a 100 legnagyobb nettó árbevételt realizáló vállalkozás közül 58 debreceni székhellyel rendelkezett 2011-ben) [12]. Jelenleg Debrecenben hat különálló iparterület található mintegy 404 ha-on, közel 9000 fös foglalkoztatottsági létszámmal. Olyan nemzetközi cégek vannak jelen ezekben az ipari parkokban, mint a National Instruments, az FAG, az IT Services Hungary (T-Systems), a TEVA, Randstad, Flexi Force. A kulturális gazdaság is meghatározó jelentőségű, ami három területre koncentrálódik a városon belül: a városközpont (Hittudományi Egyetem, múzeumok, mozik, Bábszínház, Csokonai Színház, bevásárlóközpontok, konferenciaközpont, stb.), Egyetemváros (egyetemek, Botanikus Kert, Idegen Nyelvi Központ, Konzervatórium, stb.) és a Kassai úti campus (egyetemek, rendezvényközpont, sportcsarnokok) [19]. Debrecen nagy kapacitású kereskedelmi létesítményei föleg multicégekhez kötődnek (METRO, TESCO, Debreceni Plaza, Malompark, CORA (2002), ami ma AUCHAN-ként működik. Meghatározó kereskedelmi funkciót tölt be a Piac-tömb rehabilitációjának a keretében kialakított, hatalmas bevásárlóközpont, a FÓRUM [20].

\subsection{Idegenforgalom}

Debrecen, mint komplex gazdasági szerkezetü nagyváros, kiemelkedő idegenforgalmi funkcióval bír. 2011-ben a vendégéjszakák száma a kereskedelmi szálláshelyeken 279210 volt, míg a vendégek száma 110853 fö [21]. A Központi Statisztikai Hivatal által közzétett, a 2013-as év leglátogatottabb 50 településének turisztikai statisztikájából látszik, hogy a Debrecenben eltöltött vendégéjszakák száma növekszik (2013ban 283572 vendégéjszaka). Az idegenforgalmi sikerhez természetesen hozzájárul az is, hogy a kereskedelmi szállásférőhely-kapacitás koncentrációja a térségen belül is nagyfokú. Ezek közül kiemelkedik Debrecen (13\%-os részarány) [22]. Debrecen a régió kiemelt gyógyhelye. Vonzerejét növeli, hogy a város nem csupán wellnessközpont (két termálfürdő, egy élményfürdő, egy átépítés előtt álló városi szabadtéri fürdő), hanem kiemelkedő a kulturális és gasztronómiai szerepe (színházi, zenei és képzőmüvészeti programkínálat).

\section{DEBRECEN KÖZLEKEDÉSI SAJÁTOSSÁGAI}

A városi terjeszkedés nyomán a lakóhelyi szuburbanizáció eredményeként Debrecenben is megnőtt az elővárosokból a központokba történő, viszonylag kis távolságokra irányuló mozgások szerepe, amelyek egyre nagyobb hányada nem közösségi közlekedési eszközzel, hanem a szuburbanizáció motorjának számító személyautóval történik [23, 24]. Debrecen átlagos vonzáskörzeti távolsága $29 \mathrm{~km}$ [25], amely zónából jelentős számú ingázó jár be naponta a városba (1. és 2. ábra).

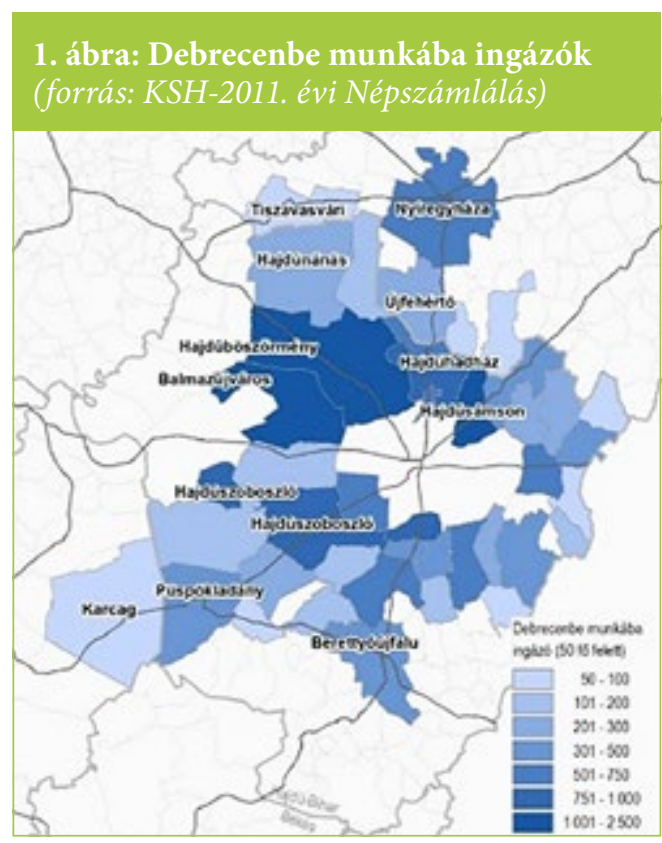

Debrecen az észak-alföldi térség legjelentősebb közúti csomópontja. A közlekedési szektorból származik a térség GDP-jének 5\%-a [26]. 2006 óta az M35 autópálya részleges kiépülésével [20] Debrecen bekapcsolódhatott az országos autópálya hálózatba. Jelenleg zajlik az M35 autópálya továbbépítése Debrecentől déli irányban, aminek megépitésével és a hozzá csatlakozó M4 autópályával létrejön a közvetlen autópálya kapcsolat Romániával. A régió legfőbb közúti tengelyvonala (Budapest-Szolnok-Debrecen-Nyíregyháza-Záhony) a 4-es számú foút áthalad a városon. 


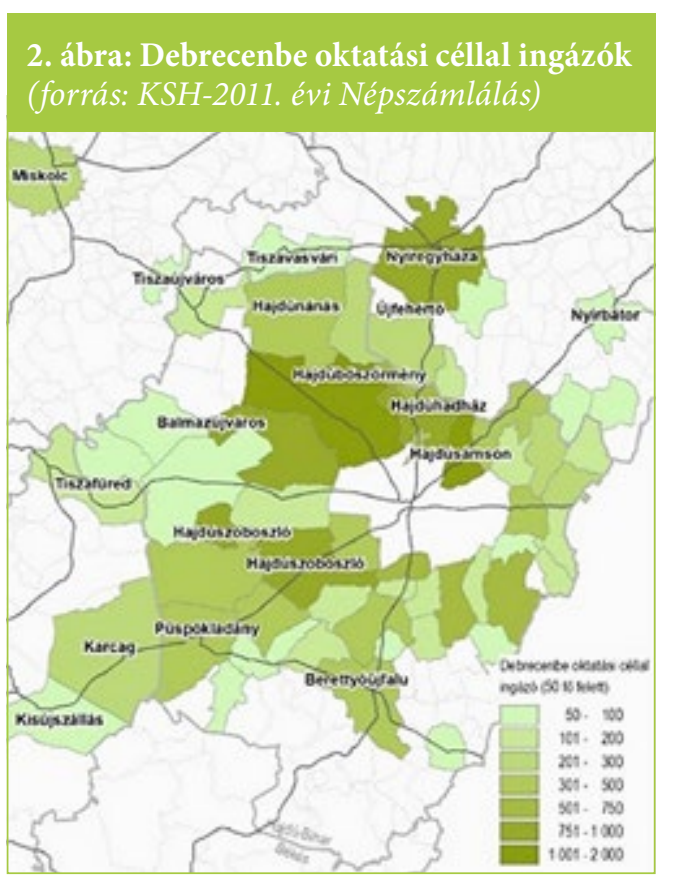

A további fóntvonalakról érkező belföldi és nemzetközi gépjárműforgalom is itt találkozik, ami miatt a várost terhelő tranzitforgalom jelentős. Ezt a forgalmat a város sugaras-gyürűs közúti hálózati szerkezete ugyan levezeti, de a szerkezetből helyenként hiányzó gyürüs elemek jelentős torlódási problémákat okoznak.

Debrecent egy friss felmérés szerint naponta mintegy 635 ezer helyváltoztatás terheli [27]. A helyváltoztatások eszközválasztásánál még mindig a személygépjármü használata - föként a városhatárt átlépő helyváltoztatások esetében - a domináns (1.és 2. táblázat).

\section{1. táblázat: Eszközválasztási megoszlás \\ Debrecen belső helyváltoztatásában, 2016 (forrás: A DMJV 2016-os közlekedési felmé- rés adatai alapján saját szerkesztés)}

\begin{tabular}{|l|l|}
\hline kerékpár + gyalogos & $28 \%$ \\
\hline tömegközlekedés & $32 \%$ \\
\hline személygépjármü & $40 \%$ \\
\hline
\end{tabular}

Magyarországon az utazások tekintetében a közösségi közlekedés sokkal fontosabb szerepet tölt be, mint általában az EU-ban. Míg az EU-ban az utazások átlag 83\%-át (2007) [26]
2. táblázat: Eszközválasztási megoszlás Debrecen városhatárát átlépő helyváltoztatásában, 2016

(forrás: A DMJV 2016-os közlekedési felmérés adatai alapján saját szerkesztés)

\begin{tabular}{|l|c|}
\hline vonat & $12 \%$ \\
\hline tömegközlekedés & $29 \%$ \\
\hline személygépjármű & $59 \%$ \\
\hline
\end{tabular}

személygépkocsival hajtják végre, addig Magyarországon ez az arány valamivel kedvezőbb, de így is a közösségi közlekedés részaránya csak 40-50\% (2007) körüli [28]. A várost érintő helyközi közösségi közlekedés rendszere két fö alágazaton keresztül, az autóbuszos (Volán társaságok) és a vasúti (MÁV Start Zrt., GYSEV Zrt.) szolgáltatással biztosítja a személyszállítást. A régió a Budapest-Szolnok-Debrecen-Nyíregyháza-Záhony kétvágányú, villamosított vasúti fóvonal mellett fekszik, amelyen $100 \mathrm{~km} / \mathrm{h}$ feletti sebességgel is közlekedhetnek a vonatok. A város vasúti kapcsolatait jellemzően ez a vasúti fővonal határozza meg, amelyhez további hét kisebb jelentőségű vonal csatlakozik.

A Debreceni Nemzetközi Repülőtér a régió és egyben a Dunától keletre fekvő térség legfontosabb repülőtere, nemzetközi repülőtér (2001), vámúttal rendelkezö, állandó nemzetközi légi határátkelő (2004) [20]. 2012-ben a Debreceni Nemzetközi Repülőtér 1250 db kereskedelmi járatán összesen 46 ezren utaztak. Forgalma valamennyi vidéki nemzetközi repülőterét megelőzi, így a budapesti Liszt Ferenc Nemzetközi Repülőtér után a második legforgalmasabbnak számító repülőtér [22]. Forgalma folyamatosan nő: 2012-ben 50000 fö, 2013ban 129231 fö, 2014-ben 145709 fö [29]. A jelenlegi menetrend szerint, illetve charter járatokkal Debrecenből légi úton elérhető TelAviv, Milánó, London, Párizs, München, Malmö, Eindhoven, Antalya, Erfurt, Zákinthosz, Korfu, Burgasz, Lipcse és Drezda [30].

\section{A DEBRECENI INTERMODÁLIS KÖ- ZÖSSÉGI KÖZLEKEDÉSI KÖZPONT (IKKK) PROJEKT BEMUTATÁSA}

Debrecenben és más hasonló európai városokban a mobilitási szükséglet gyors, tervezhető 


\section{Intermodális közlekedés}

és kiszámítható utazási feltételeket követel meg. Az IKKK célja, hogy elősegítse az utasok közlekedését célállomásaik között azzal, hogy megkönnyíti, meggyorsítja, kényelmesebbé teszi az átszállásokat, ami által az utas komfortérzete és elégedettsége növelhetö.

\subsection{Előzmények}

A projekt elsődleges célja a Debrecenben és az agglomerációban (nagyvárosi településegyüttesben) élö lakosok (267 949 fö/2013) [12], valamint a városba látogatók közlekedési lehetőségeinek fejlesztése, a Debrecen vasútállomás és környezetének (Petőfi tér), - városépítészeti szempontból illeszkedő - rendezése. E cél elérése érdekében Debrecen Megyei Jogú Város (DMJV) Önkormányzata az Európai Unió által biztosított közlekedésfejlesztési források lehetőségét megragadva a Közlekedési Operatív Program (KÖZOP) keretében pályázatot nyújtott be az IKKK létrehozásának előkészítésére, tervezésére. A benyújtott pályázat kedvező elbírálása alapján 2012-ben Debrecen bruttó $843280000 \mathrm{Ft}$ vissza nem térítendő, $100 \%$-ban európai uniós támogatást nyert (KÖZOP-5.5.0-09-11-2012-0002 azonosító számú projekt). 2012 augusztusában a beruházás volumenére és fontosságára való tekintettel a Kormány nemzetgazdasági szempontból kiemelt jelentőségű beruházássá nyilvánította a projektet (1320/2012. (VIII. 30.) Korm. határozat a Közlekedés Operatív Program keretében finanszírozott és finanszírozandó egyes kiemelt beruházások nemzetgazdasági szempontból kiemelt jelentőségü beruházássá nyilvánításáról [31]). A DMJV 2013. április 24-én megjelentette az IKKK nemzetközi, nyílt tervpályázatát. A felhívásra 37 hazai és külföldi pályamü érkezett. A tervpályázati eljárás közel négy hónapos ciklusának zárásaként az eredményhirdetés 2013. augusztus 06-án megtörtént. A DMJV egy magyarországi tervező csoporttal kezdhette meg a tervezői munkát. Magyarországon a vasútállomások állami tulajdonban vannak, ezért az országban megvalósuló intermodális közösségi közlekedési központok létrehozása - a vasútállomási érintettség miatt - kizárólag állami tulajdonú területen lehetséges. Szintén az egész országra egyöntetűen érvényes az is, hogy az uniós pályázati források lehívására, valamint a beruházás lebonyolítására állami beruházó, állami infrastruktúrafejlesztő cég jogosult, úgy mint Nyíregyháza, Miskolc, Székesfehérvár, Tatabánya-Bicske városok intermodális központjaira irányuló projekteknél a NIF Zrt. (a Kormány 1247/2016. (V. 18.) Korm. határozata az Integrált Közlekedésfejlesztési Operatív Program éves fejlesztési keretének megállapításáról [32]). Ezáltal az érintett önkormányzatok közvetlen szerepvállalása a projektekben nem lehetséges. Tekintettel tehát arra, hogy a beruházás kizárólag állami tulajdonban lévő ingatlanon valósulhat meg, elindult egy telekalakítási eljárás a debreceni önkormányzati ingatlanok állami tulajdonba adása érdekében, amely eredményeként egy helyrajzi számú, állami tulajdonban lévő építési telek kialakítását végezték el.

\subsection{A müszaki kialakítás}

Az IKKK előkészítő projekt keretében elkészített műszaki tervdokumentációk és szükséges alátámasztó dokumentációk alapján egy, a debreceni vasútállomás átépítéséhez és a Petőfi tér fejlesztéséhez szervesen illeszkedő épületegyüttes, közlekedési hálózat és térrendezés valósulhat meg a debreceni vasútállomás felvételi épületét magába foglaló ingatlanon és annak környezetében. A tervezett központ a vasútállomás jelenlegi épületének megtartásával, részleges átépítésével, valamint a közlekedési és zöldterületek kialakításával körülbelül 150 ezer négyzetméteren valósul meg. A következőkben az IKKK terveinek részleteit mutatom be közlekedési, építészeti, várostervezési és környezeti aspektusban.

\subsubsection{Közlekedési módok}

A város nagy történelmü és ikonikus temploma, a Nagytemplom a vasútállomásra reflektálva került kiépítésre. A Nagytemplomot és a közvetlen környezetében lévő Kossuth teret - a város legnagyobb rendezvény tere - a vasútállomással a Piac utca köti össze. A Piac utcán egyre növekvő a városi-közösségi élet. A számos üzlethelyiség, teraszos vendéglátó- 


\section{Intermodális közlekedés}

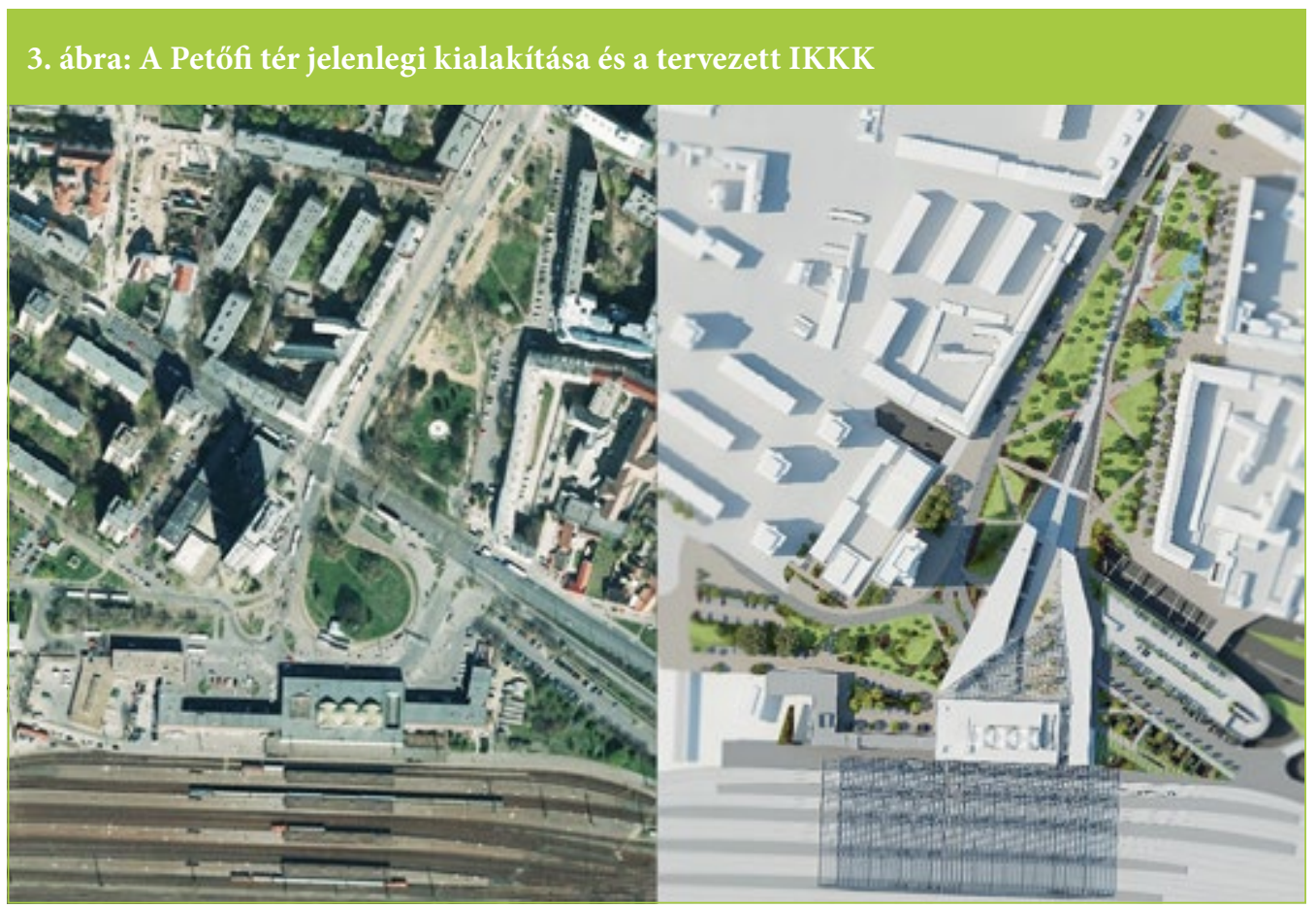

ipari egység még tovább növeli az utca népszerűségét. Ebből kifolyólag a város vezetése elkötelezte magát amellett, hogy a Piac utcát, a vasútállomás és a Nagytemplom közötti teljes hosszában sétálóövezetté alakítja át az elkövetkező néhány évben. Ha az IKKK a belvárosi térrendszerhez közelítően és öszszekapcsolhatóan valósulna meg, akkor kialakulhatna a két hangsúlyos végpont közötti gyalogos övezet, így a Piac utca teljes hosszában városközpontként lenne definiálható. $\mathrm{Ha}$ az új közlekedési központ ettől a zónától valami miatt leszakad, úgy önálló szatellitként müködne, azaz oda már csak közlekedési eszközökkel lenne érdemes eljutni. Ez esetben a Piac utca meghatározó része véleményem szerint elhalna.

Az IKKK tervének egyik legmeghatározóbb eleme az, hogy a különböző közlekedési módok - autóbusz-forgalom, személygépjármü-forgalom, tehergépjármü-forgalom - a közlekedési felületek térszín alá süllyesztésével eltünnek a felszínről. Mindezek mellett a villamos, a kerékpáros és a gyalogosforgalom keresztezés mentesen a térszínen marad.

\subsubsection{Autóbusz-közlekedés}

A helyközi autóbusz-közlekedés pályaudvara jelenleg a vasútállomástól és a helyi autóbusz szolgáltató pályaudvarától (ezek egy helyen vannak) hozzávetőlegesen $1 \mathrm{~km}$-re helyezkedik el (Külsővásártér), jelentős és felesleges - a közlekedési módváltások miatt - többletforgalmat generálva ezzel a város közösségi közlekedési hálózatában.

A közlekedési módok integrálását megteremtve a helyi Debreceni Közlekedési Zrt. (DKV) és a helyközi Észak-Magyarországi Közlekedési Központ Zrt. (ÉMKK) mint szolgáltatók által lebonyolított autóbusz-forgalom számára felszín alatti, fedett-nyitott buszpályaudvar épül megállóhelyekkel, 12 ezer négyzetméternyi területen, korszerű utastájékoztató rendszerrel. A tervek szerint a külsővásártéri helyközi buszpályaudvar megszünik. A tervezett buszpályaudvaron szóló és csuklós buszok számára létesül álláshely, valamint itt valósul meg a buszok tárolása. A tervezési megoldások lehetővé tették, hogy a buszpályaudvar területén az álláshelyeket az utasok a jármüvek által használt 


\section{Intermodális közlekedés}

úthálózat keresztezése nélkül, az esélyegyenlőségi követelményeknek megfelelően közelíthetik meg. Ezzel a korszerű megoldással lehet a baleseti kockázatokat a lehető legalacsonyabb szintre szorítani. A buszok indítására két területröl a pályaudvar északi és déli területéről történik. A déli megállóterület mentén nyolc csuklós, míg az északabbra eső megálló terület mentén tíz szóló és három csuklós autóbusz peron létesül. A buszok várakoztatása a 4-es fóút és pályaudvar között tervezett párhuzamos leálló sávon biztosítható, ahol nyolc csuklós vagy tizenkét szóló autóbusz helyezhető el. A Déli út mentén öt szóló vagy három csuklós, az Északi út mentén tizenöt szóló vagy kilenc csuklós busz további elhelyezésére is lehetőség van.

\subsubsection{Személygépjármü-közlekedés}

Egy lakossági zajérzékelési felmérés 2006-os kutatás eredménye szerint a megkérdezettek 88,35\%-ának (2006) a legzavaróbb zajforrása Debrecenben a közúti közlekedés [33], amely a leginkább a Piac utcán jelentkezik [34].

A baleseti gócpontok felszámolását maximálisan előtérbe helyező tervezési irányelv mentén haladva tervezték meg a vasútállomás előtt elhaladó, közel 20000 jármü/nap forgalmat (1150 autóbusz/nap) [35] lebonyolító országos foútvonal térszín alá süllyesztését. A 4-es számú foút térszín alatti átvezetése a Vörösmarty utcától a Vígkedvű Mihály utca jelenlegi csatlakozásánál tervezett dupla körforgalomig történik meg kb. $400 \mathrm{~m}$ hosszan. A dupla, rotációs elven müködő körforgalom a jelenleg is meglévő, a tervek szerint részben átépítendő külön szintű közúti csomópont két oldalán helyezkedik majd el.

\subsubsection{Parkolás}

A városban a növekvő motorizációs tendenciák (jelenleg: 308 személygépkocsi/1000 lakos) [35] miatt nagyfokú figyelmet kell szentelni a megfelelő számú fizető várakozóhely biztosítására. A városban közel $4100 \mathrm{db}$ parkolóhely van (mélygarázsok nélkül) [35]. A tervek szerint az IKKK projektben a 4. sz. foúttal párhuzamosan, önálló épületként jelenik majd meg egy parkolóház. A gépjármüvel Debre- cenbe érkező utasok számára közel 390 db férőhelyes, háromszintes parkolóház létesül. Az összesen kb. $11500 \mathrm{~m}^{2}$-es, egy földszint, egy I. emeleti és egy parkolótetős szinttel rendelkező parkolóházban taxiállomások, akadálymentes parkolók, hosszú idejü parkolók $(\mathrm{P}+\mathrm{R})$, gyorsparkolók $(\mathrm{K}+\mathrm{R})$, valamint fedett kialakítással 150 férőhelyes kerékpárparkolót helyeznek el, kerékpárbolttal és szerviz funkciócsoporttal.

\subsubsection{Kötöttpályás közlekedés}

A DMJV-nak két helyi kötöttpályás villamos és három trolibusz viszonylata van [12.]. Mindkét villamos vonal végállomása jelenleg a Petőfi téren üzemel a vasútállomás közvetlen közelében, a trolibuszjáratokból egy érinti a vasútállomást. A projekt megvalósítása során a villamos Petőfi téri vágányhálózata átépül. A meglévő hurok végállomás helyett négyvágányos fejállomás létesül, egy szükségmegállóhellyel, illetve az üzemi kapcsolatokkal a kocsiszín irányába. A peronok az esélyegyenlőségi követelményeknek megfelelő kialakítással valósulnak meg. A villamos a megmaradó és a tervezett épületek által közrefogott fedett térre érkezik.

\subsection{2. Építészet, várostervezés}

A most átépítésre kerülő vasútállomás helyén egykoron az az 1902-ben a Pfaff Ferenc tervezte állomásépület állt, amit az 1944. szeptember 21-ei bombatámadás teljesen elpusztított [36], és az érintett városrész is megsemmisült. A vasútállomás előtti tér a bombázás után alakult ki. A város térszerkezetében idegen, túl nagy teresedés az 1960-as évek elején, az akkori kor túlméretezett térkoncepciói szerint épült ki. A mostani tervezési koncepció azt az elvet követi, hogy ezt a müködésképtelen teret szűkíteni szükséges, és a gyalogos sürüsödéseket nem a városközpontból elvinni, hanem ahhoz minél közelebb célszerü elhelyezni. A koncepció további lényege a meglévő építészeti értékek megtartása. A jelenlegi, 1961-es állomásépület (Kelemen László tervezte) [37] nem csak építészeti, várostörténeti, hanem komoly anyagi értéket is képvisel. Az épület gazdaságosan felújítható, eredeti építészeti ér- 
tékei megtarthatók. A régi állomásépület az új építészeti elemekhez szervesen kapcsolható. Fontos ezeken túl az is, hogy a megmaradó épület funkcionális jelenléte az építés alatti, nehezen organizálható időszakban is szükséges lehet. Az épületek megtartásának pozitív oldala a költségtakarékosság. A projekt a jelenlegi épületegyüttesből csak egy minimális keleti épületszárnyat bont el, a központi utasteret magában foglaló épületszárnyat, valamint a nyugati épületet megtartja. A központi épület elé két fokozatosan szétnyíló épületszárnyat terveztek, amelyek a Piac utca sétálóövezetének végpontjaként, kapuzatként jelennek meg. A nyitott befogadó udvar folytatásaként egy fedett-nyitott üvegezett agórával kapcsolódik a meglévő fóépülethez. Ez a Piac utcából kiinduló differenciált térsor a projekt legnagyobb értéke.

A tervezési koncepció deklarált szándéka a belvárosi térszövet rehabilitálása. Ezt a célt sajátos eszközökkel igyekeznek elérni, a Petőfi térbe mélyen benyúló, beékelődő épületekkel. Mindez a térarányok teljes megváltoztatásával jár, amelynek eredményeként izgalmas térszövet alakulhat ki.

\subsubsection{A vasútállomás és kapcsolódó épület- egyïttesek}

Magasépítmények tekintetében a fejlesztés tehát a meglévő, építészetileg értékes utasforgalmi épület megtartásával, átépítésével és a kiegészítő funkcióknak helyet adó új épületek létesítésével számol. A felújított felvételi épület elé épülő, legyezőszerüen elhelyezett épületszárnyakban kereskedelmi, irodai és kiszolgáló funkciók, kormányablak, diszpécser szolgálat vendéglátóipari egységek kapnak helyet. A közönségforgalmú terek, a közlekedők és az azokat kiegészítő funkciók területe kb. $4500 \mathrm{~m}^{2}$. A meglévő épület földszintjét felújítják, az irodaszinteket kb. $2000 \mathrm{~m}^{2}$-es területen átalakítják. A központi épület előtti, két fokozatosan szétnyíló hosszanti épület a vasútállomás föépületéhez csatlakozva üvegtetővel fedett térként fejeződik be.

Az IKKK belső utasforgalmi területén jegypénztárak, információ, csomagmegőrzők, wc blokkok, jegy- és egyéb automaták találhatók. A felépítmények szervesen kapcsolódnak a terepszint alatti buszpályaudvar utasforgalmi tereihez. Az autóbuszjáratok utasperonjai, valamint a vasúti peronokhoz vezető aluljáró kereszteződésmentesen és szintben csatlakozik az utasforgalmi térhez. Épületen belül az egyes közlekedési egységek között mozgólépcsők könnyítik meg az utasok közlekedését.

\subsubsection{Zöldterületek}

Debrecen zöldterület arány tekintetében nagyon rossz helyzetben van. Egy lakosra jutó parkfelület $8,1 \mathrm{~m}^{2}$, míg az egy före jutó zöldterület is csak $8,8 \mathrm{~m}^{2}$ (2014) [30]. Ezekkel az eredményekkel Debrecen az utolsó helyen áll a magyarországi megyei jogú városok között. $A$ városszerkezet mellett természetesen $a z$ is hozzájárul ehhez az értékhez, hogy Debrecen lakosságszáma messze nagyobb, mint az átlagé [38].

A tervezett közlekedési létesítmények felszín alá helyezése lehetővé teszi a térszínen nagy kiterjedésü parkosított felületek kialakítását. A meglévő és új épületeket élhető városi terek, fedett közlekedőfelületek és parkos környezet kötik össze. A térszinten megvalósuló gyalogos és kerékpáros kapcsolatok fejlesztése mellett táj és térrendezés valósul meg, az esztétikus, környezetbarát, városi életérrel kapcsolatos elvárásoknak megfelelően.

\section{6. ÖSSZEGZÉS}

Egy sikeres város kedvező feltételeket kell, hogy nyújtson a külső kapcsolatai, így a személyszállítási csomópontjai fejlesztésében [39], biztosítva ezzel a vidéki térség fejlődését és a régiók összetartását [26]. A mai európai közlekedéspolitika elsődleges célja, hogy a városokban elösegítse egy erőforrás-hatékony, magas színvonalú mobilitási szolgáltatásokat nyújtó, versenyképes közlekedési rendszer kialakulását [40]. Ezen fejlettebb közlekedési rendszer eléréséhez szükséges az intermodális szervezési szolgáltatások segítségével megteremtett háztól házig tartó mobilitás megteremtése, a különböző közösségi közlekedési módok integrációja [41], a kollektív közleke- 


\section{Intermodális közlekedés}

dési módok és az egyéni közlekedési módok kombinálása, valamint az intelligens, akadálymentes és biztonságos városi közlekedés feltételeinek biztosítása [42].

A fejlesztési igényeknek való megfelelésért kizárólag az adott város a felelős. Ezért Debrecen a jelentkező feladatok megoldására a lehető leghatékonyabb eszközt választotta, azaz egy intermodális közösségi közlekedési központ létrehozását. A debreceni IKKK megvalósításával lehetőség nyílik majd egy versenyképes alternatíva felkínálására a személygépjármüvel végzett háztól házig tartó mobilitással szemben, ugyanis a központ egy, a város teljes területét - beleértve a külső lakóterületeket is - kielégítően lefedő (a város túlnyomó részén 300 méteren belül elérhető legalább egy megállóhely) közösségi közlekedési hálózatnak lehet egy meghatározó eszközváltó pontja. Ebbe a pontba integrálódhat a kollektív közlekedés szegmensét képviselö helyközi autóbusz és vasút, valamint közvetve a légi közlekedés, a helyi autóbusz, trolibusz és villamos szolgáltatással. A központ segítségével „egy tető alatt” megteremtődhet a kapcsolat az egyéni közlekedési módokkal is, azaz a személygépjármü közlekedéssel, kerékpár,- és gyalogosközlekedéssel és nem utolsó sorban a taxikkal.

Magyarország Kormányának az Integrált Közlekedésfejlesztési Operatív Program (IKOP) éves fejlesztési keretének megállapításáról szóló 1247/2016. (V. 18.) Kormány határozata alapján a projekt „Debreceni intermodális személyszállítási központ létrehozása” néven az IKOP kiemelt projektjeként nevesítették. Meghatározták továbbá azt is, hogy a beruházás építtetője a Nemzeti Infrastruktúra Fejlesztő Zrt. (NIF) lett. A NIF és a DMJV Önkormányzata közös és szoros együttműködésével 2017-ben elindított projekt révén megnyílt a lehetőség egy modern, hatékony, a különböző közlekedési módok közötti csatlakozást megteremtő intermodális központ megvalósítására, amely nemcsak a városban, hanem az egész megyében élők számára kényelmesebbé teszi majd a közlekedést, és egyúttal megteremti a térségben a gazdaság további fejlődésének lehetőségét.

\section{FELHASZNÁLT IRODALOM}

[1] Kondor Attila Csaba, Kovács Zoltán: Kibocsátáscsökkentés és urbanizáció: ellentmondások és párhuzamok, Magyar Tudomány, 2017. 6, $686 \mathrm{p}$.

[2] Európai Bizottság: A Bizottság közleménye, EURÓPA 2020, Az intelligens, fenntartható és inkluzív növekedés stratégiája $\operatorname{COM(2010)~2020,~}$ Brüsszel, 2010. 18. p.

[3] Kovács Zoltán: Társadalom - földrajz - bevezetés, Magyar Tudomány, 2017. 3, 258. p.

[4] Magda Pitsiava-Latinopoulou, Panagiotis Iordanopoulos: Intermodal Passengers Terminals: Design standards for better level of service - Procedia - Social and Behavioral Sciences 48, 2012 pp. 3297 - 3306.

[5] Bodnár Balázs: Az intermodalitás szakpolitikai illeszkedése - „Közlekedéstervezés és irányítás a 21. században”, konferencia kiadvány, Közlekedéstudományi konferencia, Győr, 2016. pp. 176-177.

[6] Kreutzberger, E., Macharis, C., \& Woxenius, J.: Intermodal versus unimodal road freight transport - A review of comparisons of the externalcosts.InB.Jourquin,P.Rietveld,\&K.Westin (Eds.), Transportation economics: Towards better performance systems 2006. pp. 17-42.

[7] Kenneth Sörensen, Christine Vanovermeire, Sylvie Busschaert: Efficient metaheuristics to solve the intermodal terminal location problem, Computers \& Operations Research 39 2012. pp. 2079-2090.

[8] Budapest Közlekedési Rendszerének Fejlesztési Terve, Távlati koncepció és a 2020-ig javasolt fejlesztés terve, 2008. 136. p.

[9] Magyar Útügyi Társaság (MAÚT): Intermodális közösségi közlekedési csomópontok (tervezési és bírálati útmutató), Budapest, 2012. 15. p.

[10] Charles R. Rivasplata: Intermodal transport centres: towards establishing criteria, Paper presented at the 20th Annual South African Transport Conference 16-20 July 2001.

[11] Stewart, David B.: The New Station as Interface. An Overviev of Image, Function and Amenity, Japan Railway \& Transport Review, 1995. pp. 6-13.

[12] KSH - Magyarország településhálózata 1., Agglomerációk, településegyüttesek 2014.

[13] KSH - Hajdú-Bihar megye statisztikai évkönyve 2014. 
[14] Süli-Zakar István, Kecskés Zoltán: Debrecen, the city of spa, (the thermal water based health tourism - the establishment and development of Debrecen's health spa), Central European Regional Policy and Human Geography, Year V., no. 1, 2015. pp. 55-70.

[15] Dr. Kőszegfalvi György: A magyarországi városhálózat a 2011-es népszámlálás adatainak tükrében, Területi statisztika, 2014. 54(2) pp. 178-194.

[16] Wusching Á. Tamás: A nemzetközi hallgatók tanulmányi célú mobilitásának jellegzetességei Pécs és Debrecen példáján, Tér és Társadalom, 31. évf., 2. szám, 2017. 72. p.

[17] Debreceni Egyetem https://www.unideb.hu/hu/ debreceni-egyetem-szamok-tukreben- letöltés: 2017. augusztus 27.

[18] Schneider Gábor: Formálódó új európai növekedési központok? A közép-európai térség metropoliszrégióinak sajátosságai és kihívásai, Tér és Társadalom 24. évf. 2010/1. pp. 155-173.

[19] Süli-Zakar I., Ekéné Zamárdi I., Kozma G., Teperics K.: Debrecen kulturális gazdasága és gazdasága, Földrajz és turizmus, Tanulmánykötet, Dr. Hunusz Árpád 60. születésnapjának tiszteletére, (szerkesztette: Dr. Kókai Sándor), 2006. pp. 317-318.

[20] Martonné Erdős Katalin, Vasvári Mária: Debrecen turisztikai fejlesztései és azok hatásai az ezredforduló után, Emberközpontú társadalom, Tiszteletkötet Ekéné Dr. Zamárdi Ilona 70. születésnapjára (szerkesztette: Kozma Gábor), DIDAKT Kft., Debrecen, 2013.

[21] Csomós György: Magyarország gazdasági központjainak pozícióváltozása 1992 és 2011 között 2013.

[22] KSH - Idegenforgalmi tendenciák, sajátosságok Észak-Alföld megyéiben 2013

[23 Erdősi Ferenc: A fenntartható közlekedés megvalósíthatóságának nehézségei, Konferencia kiadvány, Földrajzi Konferencia, Szeged 2001. 8. p.

[24] Kovács Zoltán: Városok és urbanizációs kihívások Magyarországon, Magyar Tudomány, 2017. 307. p.

[25] Szalkai Gábor: Várostérségek lehatárolása a közúti forgalom nagysága alapján a magyar határok mentén, Tér és Társadalom XXIV. évf. 2010. 183. p.

[26] Novák Géza, Varsányi Tamás: The transport situation in the Great Plain, Regional Statistics, Volume 14 (51) special issue, 1/2011. 135. p.
[27] Debrecen Megyei Jogú Város Polgármesteri Hivatal Városfejlesztési Főosztálya - adatszolgáltatás

[28] Dr. Horváth Balázs: Rugalmas közlekedési rendszerek a fenntartható városért, Települési környezet konferencia , Debrecen, 2007. 233. p. http://geo.science.unideb.hu/taj/dokument/ telkonf/dokument/horvath_b.pdf - letöltés: 2017. augusztus 27.

[29] KSH - Magyar Statisztikai évkönyv 2014

[30] Debrecen Airport, http://www.debrecenairport. com - letöltés: 2017. augusztus 27.

[31] http://www.kozlonyok.hu/nkonline/MKPDF/hiteles/mk12114.pdf - letöltés: 2017. szeptember 3.

[32] http://www.kozlonyok.hu/nkonline/MKPDF/hiteles/MK16070.pdf - letöltés: 2017. szeptember 3.

[33] Baros Zoltán: Lakossági vélemények Debrecen zajterheléséről, Földrajzi közlemények, 136. évfolyam, 4. szám, 2012. 392. p.

[34] Baros Zoltán: Települési környezeti minőség, fenntarthatóság és városmarketing - különös tekintettel a zajterhelésre és az önkormányzatok szerepére, Tér és Társadalom, 26. évf., 3. szám, 2012.61. p.

[35] Debrecen fenntartható közlekedésfejlesztési stratégiája és programja, 2013.

[36] Horváth Attila: Légitámadás a debreceni Nagyállomás ellen 1944. szeptember elsején, Új nézőpont - Hajdú-Bihar Megyei és Debreceni Honismereti Egyesület online folyóirata http://ujnezopont.biharkutatas.hu/wp-content/ uploads/2013/10/3_resz.pdf - letöltés: 2017. szeptember 3.

[37] Mezei István: A magyar vasút krónikája a XX. században, MÁV Vezérigazgatóság, 2009.

[38] Csomós György, Kulcsár Balázs: A magyarországi NUTS 2 régiók policentrikusságának vizsgálata - Debreceni Müszaki Közlemények, 2009. 10. p.

[39] Enyedi György, A sikeres város, Tér és Társabalom11. évf. 1997/4. pp. 1-7.

[40] Stratégia Konzorcium: Nemzeti Közlekedési Infrastruktúra-fejlesztési Stratégia, Stratégiai Dokumentum, Budapest, 2014. pp. 20-21.

[41] Európai Bizottság: FEHÉR KÖNYV - Útiterv az egységes európai közlekedési térség megvalósításához - Úton egy es és eröforrás-hatékony közlekedési rendszer felé - Hatásvizsgálat SEC(2011) 359, Brüsszel, 2011.

[42] Európai Bizottság: ZÖLD KÖNYV, A városi mobilitás új kultúrája felé COM(2007) 551, Brüsszel, 2011. 3. p. 


\section{Intermodális közlekedés}

\section{Intermodal transport centre in Debrecen}

The publication combines successfully the needs of the city as a settlement with those of the implemented foreign examples, and connects the undividable basic principles of urban policy and transport policy.

The approach from the perspectives of geography and settlement structure, and the presentation of the intermodal centre as an optimal solution mean a particular value, which ensures the unity of local and interurban transport.

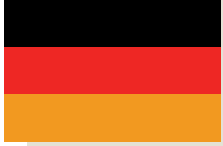

Intermodales Transportzentrum in Debrecen

Die Publikation versetzt erfolgreich die Bedürfnisse der Stadt als Siedlung mit denen der realisierten ausländischen Beispiele und verbindet sie mit den unteilbaren Grundprinzipien von Stadt- und Verkehrspolitik.

Der Ansatz aus der Perspektive der Geografie- und Siedlungsstruktur und die Darstellung des intermodalen Zentrums als optimale Lösung stellen einen besonderen Wert dar, der die Einheit von Nahund Fernverkehr gewährleistet.

\section{E számunk lektorai}

Domokos Ádám Horváth Lajos

Dr. Katona András Kövesné dr. Gilicze Éva - Dr. Tóth János

Dr. Török Ádám - Dr. Zahumenszky József

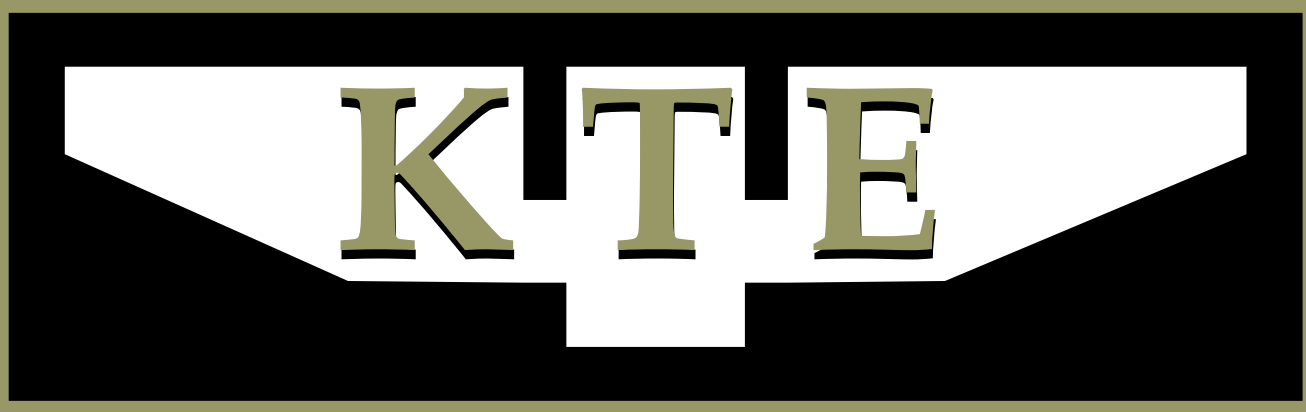

